International Journal of Child, Youth and Family Studies (2015) 6(2): 252-274

\title{
A DECADE OF DISCONNECTION: CHILD CARE POLICIES IN CHANGING ECONOMIC TIMES IN THE CANADIAN CONTEXT
}

\author{
Patrizia Albanese and Ann Rauhala
}

\begin{abstract}
This article brings together findings from two studies that focus on child care in Canada. The first maps the coverage of child care over the first decade of the 21st century in four Canadian daily newspapers. It shows that the voices of children, mothers, and child care providers are virtually absent from policy discussions. The second study, which remedies the parental invisibility identified by the first study, relies on interviews with mothers of young children in two jurisdictions with distinctive approaches to child care - the Provinces of Ontario and Quebec. This article looks at the impact on gender roles, identities, and relations of the rise in women's non-standard, service-sector employment and compares the complex task of creating and managing formal and informal nonparental child care in rural and semi-rural communities in the two policy jurisdictions (Ontario and Quebec). It seeks to understand the ways in which the neo-liberal reconfiguration of local economies affects the experiences of employed, non-urban women with young children - mitigated or exacerbated by provincial policy - through documenting the strategies that mothers adopt to face new, increasing challenges when negotiating this family-market-state nexus. This paper focuses on unique challenges some rural mothers encounter and the strategies they develop to address their changing child care needs. It also shows how absent these realities are from the coverage of child care in Canadian newspapers. The paper argues that high quality child care should be a national priority for healthy child development and better family outcomes.
\end{abstract}

Keywords: child care, media coverage/newspapers, gender, Canada, Quebec

Patrizia Albanese, Ph.D. is a Professor of Sociology at Ryerson University, 350 Victoria Street, Toronto, Ontario, Canada, M5B 2K3. Telephone: (416) 979-5000, extension 6526. E-mail: palbanes@soc.ryerson.ca

Ann Rauhala, Ph.D. is a Professor in the School of Journalism, Ryerson University, 350 Victoria Street, Toronto, Ontario, Canada, M5B 2K3. Telephone: (416) 979-5000, extension 6403. E-mail: arauhala@ryerson.ca 
It seems easier to find doggy daycare than it is to find adequate care for young children in this country. We have come to accept that dogs need "social" interaction with other animals when we are at work, but somehow do not appear to believe the same to be true for young children. We seem to know what is needed to raise healthy pets, but what about healthy children? Our national - limited and misnamed - "Universal Child Care Benefit" assumes that a stay-at-home parent/mother is the best provider of care, given that the funds allotted to eligible families cannot cover the cost of any type of nonparental care (more on this below). While having a stay-at-home parent/mother caring for children may be the best situation for some children, it is not feasible for most Canadian families today. The current economic climate, coupled with the rise of neo-liberal policies and the retrenchment of the welfare state, mean that more people, especially women/mothers, are working for pay in increasingly precarious jobs. More parents are working multiple part-time jobs, doing shift or contract work, or are self-employed, and even then, struggling to make ends meet (LaRochelle-Côté \& Uppal. 2011; Galarneau, 2010). As a result, there is a growing need for affordable, high-quality, non-parental child care at precisely the time that the national government has quashed all discussions and initiatives surrounding the creation of a national child care strategy. The facts are clear: Canadian parents say they need affordable, high-quality child care governed by solid social policies. That is exactly what most parents don't have. As a result, families struggle and children suffer out of sight of most Canadians, as parental voices are reflected in neither federal policy nor public discourse. Let us consider the case.

This paper brings together findings from two studies. In the first study, we draw upon our joint project on the digitally available media coverage of child care between 2000 and 2007 in four Canadian dailies. ${ }^{1}$ The second study involves interviews with mothers of young children in two policy jurisdictions with very different approaches to child care, on either side of the Ottawa Valley in Ontario and Quebec. ${ }^{2}$ The interviews with mothers highlight the constant need and worry faced by mothers in their quest for affordable, accessible, high-quality child care. The newspaper study, using digitally available news stories, maps the coverage of child care and child-care policy in this country to determine whether and when the needs of mothers are deemed as a subject worthy of news coverage. Both projects remind us of the importance of having strong and sound social policies that support children and families - especially in light of changing economic circumstances.

\section{Need for Child Care with the Rise of Women's Non-standard Employment}

A recent Canadian labour force survey revealed that there were employment gains in professional, scientific and technical services, in accommodation and food services, in public administration and in agriculture; while manufacturing posted a notable decline (Statistics Canada, 2013). While this may seem cause for celebration, in support of the view that we are seeing growth in the knowledge-based economy, the flip side is that for

\footnotetext{
${ }^{1}$ Funded by the Ryerson University Interdisciplinary Research Fund.

${ }^{2}$ Funded by SSHRC, Standard Research Grant, 2008-2011.
} 
International Journal of Child, Youth and Family Studies (2015) 6(2): 252-274

the past three decades, a fundamental restructuring of the Canadian economy, driven by global economic change, has seen the decimation of what were once well-paid, unionized manufacturing jobs.

While it is true that the share of employment accounted for by knowledge workers has increased in all regions, and that knowledge workers have become "a highly-prized commodity", it is also well documented that we are seeing a bifurcation of jobs and earnings in the rapidly growing service sector (Hughes \& Lowe, 2000). That is, by 2011, while some three-quarters of Canadians worked in the service sector, of the 10 broad occupational categories, the sales and services category was the largest, where the retail sector alone employed 11.5\% of the country's paid workers (Statistics Canada, 2013). Statistics Canada also noted that among the 500 occupations listed in the National Household Survey, the most common occupation for women was retail salesperson, accounting for $4.7 \%$ of all employed women, followed by administrative assistant (4.0\%), registered nurse/psychiatric nurse (3.4\%), cashier (3.3\%), and elementary school and kindergarten teacher (2.9\%) (Statistics Canada, 2013). Similarly for men, the most common occupation was retail salesperson, accounting for 3.3\% of all employed men, followed by transport truck driver (2.9\%), retail trade manager (2.5\%), carpenter $(1.7 \%)$, and janitor, caretaker and building superintendent (1.7\%) (Statistics Canada, 2013). As a result of these trends, instability and inequality in family earnings have grown since the 1990s (Morissette \& Ostrovsky, 2005).

Some have argued that the negative trends of the 1990s, including high unemployment, slow economic growth, and the rise in part-time employment (at the expense of full-time work) were reversed in recent years (Cross, 2007). On the other hand, other sources reveal that while unemployment rates have improved since the 2008 recession, they continue to fluctuate (employment growth slowed in 2013), and not all parts of the country have shared equally in the improvements (Bernard \& Usalcas, 2014; Statistics Canada, 2014). The relatively well-paid manufacturing sector remains one of the weakest of the economy (Statistics Canada, 2013). Most economic gains have occurred in western Canada, and especially Alberta, while Ontario has been hard hit by reduced activity in manufacturing, and in the auto industry in particular (Akyeampong, 2007; Statistics Canada, 2014). As noted above, more Canadians are (involuntarily) working part time - often multiple part-time jobs - temporary (contract, seasonal, or casual) jobs, shift work, or are self-employed, and struggling to stay afloat.

According to Statistics Canada, in 1980, the ratio of household debt to personal disposable income was 66\%. By 2011, that ratio surpassed $150 \%$, meaning that households owed more than $\$ 1.50$ for every dollar of disposable income (Chawla \& Uppal, 2012). How does that affect child care? With widespread worker displacement (White, 2003), an increasing proportion of families find themselves relying on individuals holding multiple jobs and/or having multiple incomes per household. While women's growing labour force participation rates may be rooted in their rising levels of education and their greater desire for economic independence, families increasingly depend on two incomes to make ends meet. This trend is not new. Women have been entering the labour force in large numbers since the end of World War II, but there are 
International Journal of Child, Youth and Family Studies (2015) 6(2): 252-274

differences today that make child care a crucial concern. While fertility rates remain low (with a slight increase in recent years), the proportion of women with young children in the labour force has, for the most part, been increasing steadily. By 2009, almost $73 \%$ of women with children under the age of 16 living at home were in the workforce, as were $66.5 \%$ of mothers with young children under the age of 6 (Ferrao, 2010). What is different now is that more women, especially women with young children, need and want to enter the labour force, yet not all can or do, at least not without assuming additional challenges related to finding non-parental care for their children. Roy (2006) notes that one of the most striking differences in women's rates of participation in the labour force across the country has been among women with at least one child under the age of 6 . In Alberta, the participation rates of women with children under the age of 6 actually fell in 2005 (from 67.9\% in 1999 to 64.9\%), in sharp contrast to almost all other provinces, except Manitoba, that showed increases (Roy, 2006). With Alberta's economic prosperity, more Albertan families may be in the position to afford one income and more stay-at-home mothers, yet in 2004 the province also had only 47,959 child-care spaces for the 163,400 mothers with preschoolers (Roy 2006).

By contrast, Quebec families used child care more, since more spaces were available and they were charged less. As a result of available care, Quebec women's labour force participation rates went from being the lowest in the country, well below the Canadian average in 1976, to surpassing the national average in 2005 (Roy, 2006).

For most families with young children - except perhaps some in Quebec (more on this below) - child care remains one of the largest expenses of raising a child, and this has had an impact on the number of women who can and do enter the labour force, subsequently also affecting women's experiences when they try to balance paid work and family responsibilities.

Not only are there more women with young children seeking to enter the workforce, but there is also a recent surge in the number of preschoolers. Statistics Canada has reported that the population of children aged 4 and under increased $11.0 \%$ between 2006 and 2011, making this the highest growth rate for this age group since the 1956 to 1961 period during the baby boom (Statistics Canada, 2012). Of these children, most lived in dual-earner, two-parent families and required some form of non-parental care. That said, Ferns and Friendly (2014) reported that in 2012, there were full- and parttime, centre-based child care spaces for only $22.5 \%$ of Canadian children under the age of 6 - a slim increase from the $21.8 \%$ in 2010 . This predicament is even worse for children under the age of 12 , where only $20.5 \%$ have a regulated space, and even then, there is considerable variation across provinces.

Just as spaces are limited, they are also prohibitively expensive. In 2011-12, Ferns and Friendly (2014) note that provincial/territorial funding allocations to regulated child care totalled $\$ 4,016,815,891$, with Quebec accounting for $60 \%$ or $\$ 2,392,649,000$ of this amount (more on reasons for this below). According to a report of the Organisation for Economic Cooperation and Development (OECD), the cost of centre-based child care is most expensive for working couples in English-speaking countries including Canada, along with Portugal and Switzerland (Immervoll \& Barber, 2005). The study found that 
International Journal of Child, Youth and Family Studies (2015) 6(2): 252-274

in these countries, out-of-pocket expenses for couples with two young children can consume as much as $20 \%$ to $40 \%$ of the family budget for the year. In Canada, child-care expenses cost families between $27 \%$ and $42 \%$ of household income, making it among the most costly of OECD countries (Immervoll \& Barber, 2005).

According to Ferns and Friendly (2014), in 2012, the Canada-wide median monthly fee for infant care was \$761; for toddler care, \$696; and for pre-school aged care, $\$ 674$. The lowest fees for infants $-\$ 152$ per month (\$7 per day) or $\$ 1,824$ per year - were paid by Quebecois parents, while the highest fees - \$1,152 a month or \$12,516 per year (i.e., more than average university tuition) - were paid by Ontario parents (Ferns \& Friendly, 2014). These variations in costs and availability are the result of the absence of a national policy and of the patchwork of policies that criss-crosses the country.

\section{Child Care Policy in Canada, Ontario, and Quebec}

More than 35 years ago, Canada published the findings of the Royal Commission on the Status of Women (1970). The document forcefully declared the need for a universal, affordable child care program as a stepping stone toward women's equality. In the decades since, promises of a national child care strategy have come on and off political agendas with few concrete results (Albanese, 2011a). Even when the discourse around child care shifted to a more child-centred social investment strategy, demonstrating the contribution of quality child care to child development, children's rights, and even economic development (see Abner, Gordon, Kaestner, \& Korenman, 2013; Hübenthal \& Ifland, 2011; Warner \& Prentice, 2013), Canadians have seen few improvements in child care policy (Friendly, Beach, \& Turiano, 2002; Friendly, Beach, Ferns, \& Turiano, 2007; Friendly \& Prentice, 2009; Organisation for Economic Cooperation and Development [OECD], 2004, 2006; Scherer, 2001).

Canada - and this is true for Ontario - has been classified as a "liberal welfare state" (Esping-Andersen, 1990), which relies on the free market rather than solid state support to families through generous social programs. Canada's family policies are for the most part limited, targeted, and often not very family-friendly. Quebec's social policies, on the other hand, are closer to a social democratic model (Baker, 2006; Krull, 2007; Albanese, 2011b). Since the mid-1990s, Quebec began transforming its policies, introducing more feminist-informed programs aimed at integrating paid work and family, promoting gender equity, and reducing family poverty (Albanese 2011b; Roy \& Bernier, 2007; Jenson, 2001). One of the province's major policy reforms came in 1997, when it introduced $\$ 5$ per day (increased to $\$ 7.00$ per day in 2004) child care for children using care at least 3 days a week, regardless of family income and employment status (Albanese 2011b; Government of Quebec, 2003, 2006; Albanese, 2006; Tougas, 2001a, 2001b, 2002a, 2002b; Bégin, Ferland, Girard, \& Gougeon, 2002).

Since the late 1990s, the federal, provincial, and territorial governments appeared to have been making progress toward improving access to quality child care across the country. See the National Children's Agenda in 1997 (National Children's Alliance, 1998; Government of Canada, 1997); the Federal/Provincial/Territorial Early Childhood 
International Journal of Child, Youth and Family Studies (2015) 6(2): 252-274

Development Agreement in 2000 (Government of Canada, 2001); the Multilateral Framework on Early Learning and Child Care, 2003 (Child Care Canada, 2003), as well as the 2005 agreement between the Quebec and Federal governments (Government of Canada and Government of Quebec, 2005).

The Multilateral Framework (Child Care Canada, 2003) built upon agreements reached between federal, provincial, and territorial governments on early childhood development, and was intended to guide new investments in regulated early learning and child-care programs, particularly for children under age 6 . Its prime objective was to support the participation of parents in employment or training by improving access to affordable, quality child care. Ministers responsible agreed to the Framework in 2003, and by 2005 the federal budget announced a national Early Learning and Child Care Initiative. The Liberal budget committed $\$ 5$ billion, to be spent nationally over five years, with $\$ 700$ million paid into a third-party trust in the 2005 budget year. The provinces were given the flexibility to draw on these funds, while a framework for quality programs was being developed (Government of Canada and Government of Quebec, 2005; Government of Canada, 2004). However, after the 2006 national election, the federal Conservative minority government replaced the funding commitments of their Liberal predecessors with their "Universal Childcare Benefit” which gives families \$100 monthly (before tax) for each child under the age of 6 years, and professes to provide parents with "more choice in child care" (Conservative Party of Canada, 2006; Government of Canada, 2006; Ballantyne, 2008). As a result, in most of the country child care spaces remain expensive, in short supply, and are perceived, both privately and publicly, as the individual (and as we have seen, invisible) responsibility of parents.

\section{Literature on Child Care Coverage in the Media}

Despite child care's extensive economic and political implications, and its importance in relation to women's equality and rights, there is scant research assessing how the media in Canada covers this issue. Research done in the United States has revealed a paucity of news coverage of child care there and we are no better off in Canada (see Dorfman \& Woodruff, 1999; McManus \& Dorfman, 2002).

Kunkel, Smith, Suding, and Biely (2002) analyzed news coverage of child welfare issues in 12 American newspapers and four national television networks. The study found that $90 \%$ of stories were about youth crime/violence and child abuse/neglect. Other categories of child welfare, child care among them, were almost invisible (see Davis 2003; Cottle, 2003; De Swert \& Hooghe, 2010).

Canadian researchers have on occasion turned their attention to press coverage of child care. For example, Theriault (2006) analyzed the National Post's coverage by focusing on its December 2004, series “The Nanny State”. Theriault argued that the series was an illustration of conservative opposition to the Liberals' proposal to implement a national program. He concludes that the newspaper presents an inaccurate portrait of the proposed child care system as a massive, top-down, government-run program. Meanwhile, Rinehart writing in Policy Options (2007) and Canadian Journal of 
International Journal of Child, Youth and Family Studies (2015) 6(2): 252-274

Media Studies (2008), argued that media coverage of child care during the 2006 federal election was "shallow and lacking in critical analysis" (2007, p. 48). Like Rinehart (2007, 2008) we were interested in how child care was written about in Canadian newspapers, but we were especially focused on knowing who was used as sources and how they were used, as well as how child care issues were framed, particularly during Canadian elections, when child care policy seems to have been a key election issue (Rauhala et al., 2012; Albanese et al., 2010). Here is a brief overview of what we found by collecting and analyzing coverage over a significant 7-year period.

Between 2000 and 2008, Canada had an unprecedented four federal elections (see Table 1). In two of these, given the flurry of advocacy work and federal-provincial negotiating, child care was a key issue, as outlined in party platforms and campaigns. Child care seemed to be a special focus of attention in the January 2006 federal election (See Table 1).

Table 1

Federal Election Dates and Length of Campaigns

\begin{tabular}{|c|c|c|c|c|}
\hline $\begin{array}{c}\text { General } \\
\text { Election }\end{array}$ & $\begin{array}{c}\text { Start of Campaign } \\
\text { (yyyy.mm.dd) }\end{array}$ & $\begin{array}{c}\text { Election Day } \\
\text { (yyyy.mm.dd) }\end{array}$ & $\begin{array}{c}\text { Length of } \\
\text { campaign (days) }\end{array}$ & Outcome \\
\hline $40^{\text {th }}$ & 2008.09 .07 & 2008.10 .14 & 37 & Conservative Minority \\
\hline $39^{\text {th }}$ & 2005.11 .29 & 2006.01 .23 & 55 & Conservative Minority \\
\hline $38^{\text {th }}$ & 2004.05 .23 & 2004.06 .28 & 36 & Liberal Minority \\
\hline $37^{\text {th }}$ & 2000.10 .22 & 2000.11 .27 & 36 & Liberal Majority \\
\hline
\end{tabular}

Source: Constructed from Parliament of Canada (on-line)

\section{Project 1}

Our study of how mainstream media covered child care focused on four newspapers chosen for their relative prominence in Canadian journalism and for their distinctive ideological flavours. Research assistants combed through digital records, searching for the terms "childcare”, "child care”, "daycare”, "day care”. We sampled the National Post and the Globe and Mail, which claim to serve a national audience, and the Toronto Star and Ottawa Citizen, which are thought to exert influence beyond their geographical reaches. Each of these exhibits an ideological position. The Toronto Star (owned by the Torstar Corp.), has a history of advocacy for social justice and is regarded as liberal or left of centre. The Globe and Mail (owned by CTVglobemedia Inc.), maintains that its readers are the "key decision-makers of Canadian households, businesses and governments” (Globe and Mail, 2010) and is regarded as centrist. Occupying the right side of the political spectrum, the National Post has been labelled a right-wing, highbrow broadsheet that caters to the political and corporate elite (Greenberg, 2000). It is owned by Postmedia Network Inc., also parent company of the 
International Journal of Child, Youth and Family Studies (2015) 6(2): 252-274

Ottawa Citizen (Canadian Newspaper Association, 2008). The Citizen claims that along with its website, half a million residents of Canada's capital peruse it each week.

The team searched each paper for January 2001, to work out recording, coding, and sampling issues. The co-investigators and assistants developed a set of rules and guidelines for including and discarding stories. For example, the team decided to exclude letters to the editor - since they do not necessarily reflect a paper's stance, but to keep editorials since they do - and include articles in which one of the four search terms appeared in the first to fifth paragraphs and also once elsewhere in the rest of the body.

We identified and collected all articles about child care from 2000 to 2007, recording the stories' headline, word count, and placement. Spreadsheets of eligible articles were analyzed to determine the total number of articles for 2000 through 2007 (see Table 2).

\begin{tabular}{|l|l|l|l|l|l|}
\hline \multicolumn{5}{|l|}{ Table 2} \\
Number of Articles per Year, 2000-2007, for Four Major Canadian Newspapers \\
\hline Year & Globe & Star & Post & Citizen & Total \\
\hline 2000 & 49 & 96 & 87 & 60 & 292 \\
\hline 2001 & 47 & 40 & 46 & 29 & 162 \\
\hline 2002 & 39 & 56 & 42 & 30 & 167 \\
\hline 2003 & 56 & 75 & 60 & 50 & 241 \\
\hline 2004 & 43 & 83 & 73 & 57 & 256 \\
\hline 2005 & 56 & 99 & 121 & 110 & 386 \\
\hline 2006 & 137 & 159 & 142 & 123 & 561 \\
\hline 2007 & 71 & 119 & 61 & 77 & 328 \\
\hline Total & 498 & 727 & 632 & 536 & 2,393 \\
\hline
\end{tabular}

We have seen a steadily growing need for affordable child care in Canada. So we wondered whether this growing demand for non-parental care coincided with growing attention to child care in major Canadian dailies.

We found that coverage was scant, except for during elections. In fact, child care moved in and out of the spotlight, migrating around the pages of four major dailies, often 
virtually disappearing. Except for during elections, we deduced that newspaper editors deemed child care of little relevance to readers.

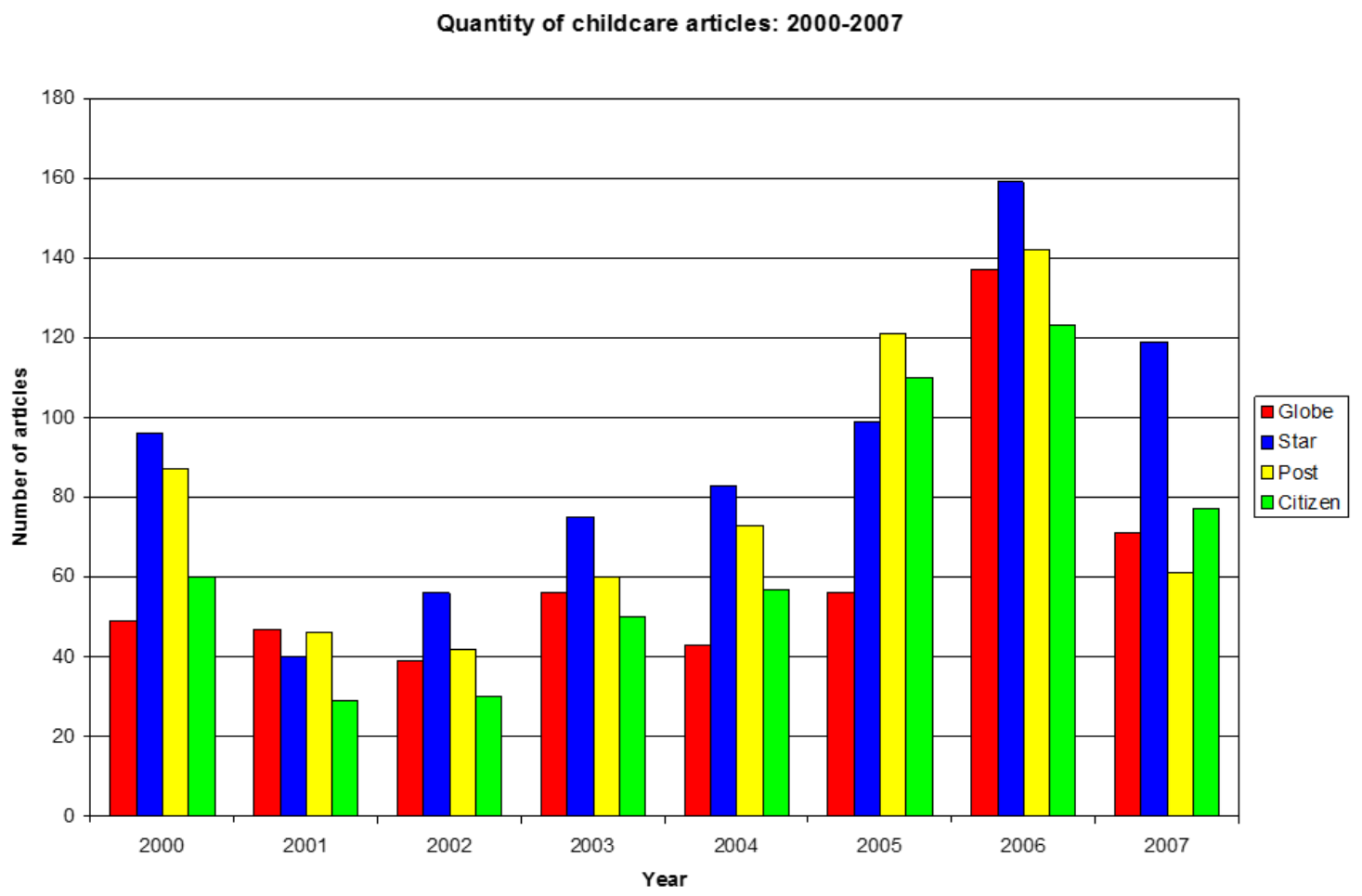

Figure 1. Quantity of Articles about Child Care in Major Canadian Newspapers.

Once we had collected data on overall coverage and assembled accessible spreadsheets of every article published in the four dailies from 2000 to 2007, we were able to drill deeper, to examine the framing used, the sources who were interviewed, and the ways in which the coverage reflected the ideological tenor of the publications. We asked:

- How has child care been framed - women's issue/family-oriented; market issue; institution-oriented (Teghtsoonian, 1993, 1995) - in two newspapers during the 2004 and 2006 federal elections?

- Which sources (who) have been used and how have they been used across the two papers and over the two elections?

We hypothesized that:

- The Toronto Star would be the more progressive/democratic/womanfriendly paper compared to the National Post. 
International Journal of Child, Youth and Family Studies (2015) 6(2): 252-274

- More female (parent, politician, and activist) and "expert” sources would be used in the Star, compared to the Post.

We (hoped) expected that mothers would be reflected in and used as key sources in news stories, especially during election campaigns (Gidengil \& Everitt, 2003; Gidengil et al., 2005; Gidengil et al., 2006). We did not find this to be the case. We also found that child care was not written about as a women's issue. Women were rarely asked or quoted. The argument for child care as a women's right/issue was rarely raised. Male first sources outnumbered female first sources in both newspapers, in both time periods, yet the Star had more female first sources (2 female first sources in 2004; 4 female in 20056) than The Post (0 female first sources in 2004; 4 female in 2005-6).

It was not surprising to find that the terms "women" and "mother" appeared in far fewer stories than the term "parent" or "family" in both newspapers, during both election campaigns (Table 3).

\begin{tabular}{|c|c|c|c|c|c|c|c|c|}
\hline \multicolumn{9}{|c|}{$\begin{array}{l}\text { Table } 3 \\
\text { Number of Newspaper Stories Including at Least One Mention of Various Terms }\end{array}$} \\
\hline & \multicolumn{2}{|c|}{$\begin{array}{l}\text { Star, } \\
2004\end{array}$} & \multicolumn{2}{|c|}{$\begin{array}{l}\text { Post, } \\
2004\end{array}$} & \multicolumn{2}{|c|}{$\begin{array}{c}\text { Star, } \\
2005-2006\end{array}$} & \multicolumn{2}{|c|}{$\begin{array}{c}\text { Post, } \\
2005-2006\end{array}$} \\
\hline & $\#$ & $\%$ & \# & $\%$ & \# & $\%$ & \# & $\%$ \\
\hline $\begin{array}{l}\text { Total Stories During } \\
\text { Campaign }\end{array}$ & 14 & & 16 & & 43 & & 60 & \\
\hline "Woman" & 5 & 35.7 & 4 & 25.0 & 5 & 11.6 & 13 & 21.7 \\
\hline "Mother" & 3 & 21.4 & 2 & 12.5 & 10 & 23.3 & 8 & 13.3 \\
\hline "Parent" & 6 & 44.4 & 9 & 56.3 & 25 & 58.1 & 41 & 68.3 \\
\hline "Family" & 7 & 50.0 & 5 & 31.3 & 55.8 & 55.8 & 35 & 58.3 \\
\hline "Choice" & 0 & 0.0 & 8 & 50.0 & 48.8 & 48.8 & 26 & 43.3 \\
\hline
\end{tabular}

Again, interestingly, the gender neutral term "parent" appeared in 68\% of Post stories in 2005-6, compared to the term "mother," which appeared in 13.3\% of stories and the term "woman" which appeared in $21.7 \%$ of stories in the Post in the 2005-6 campaign (Albanese, Rauhala, \& Hache, in press).

The relative absence of mother's views on child care was also evident when we analyzed which category of sources was cited first in news stories. We found that the most cited "experts" on child care in the 2005-6 election were politicians. Parents were cited as first sources in less than $10 \%$ of news sources in all four papers.

- First Source: Politicians made up the bulk of first sources in each of the four papers:

- $69.35 \%$ of stories in the Citizen,

- $66.67 \%$ of stories in the Star,

- $57.58 \%$ of stories in the Globe, and 
International Journal of Child, Youth and Family Studies (2015) 6(2): 252-274

- $51.11 \%$ of stories in the Post.

- $\quad$ Parents were first source cited in:

- $9.09 \%$ of stories in the Globe,

- $8.89 \%$ of stories in the Post,

- $7.69 \%$ of stories in the Star, and

- $6.45 \%$ of stories in the Citizen.

Pro-child care advocates fared worse: 0 as first sources in Star; $6.67 \%$ of stories in Post; $6.06 \%$ of stories in Globe; and $1.61 \%$ of stories in Citizen (Albanese, Rauhala, \& Hache, in press).

Overall, we found that child care is ignored by media, except at a few key points in time and despite its obvious economic weight. When it is covered, stories overlook parents as key sources of information. Further, despite our expectations, even a more "left-wing" publication failed to capture the views of parents, women, and mothers, precisely at a time when precarious work made child care a necessity for an increasing number of Canadian families. In sum, parental voices are reflected in neither federal policy, nor in public discourse, rendering invisible a desperate scramble for services that is detrimental to their health and to the well-being of their children.

\section{Project 2}

To help fill some of the gaps in what we see and know about parental needs surrounding child care, the second project includes first-hand accounts from mothers with young children who relied on non-parental child care in parts of rural Ontario and Quebec. In the summer of 2009, Albanese conducted 55 interviews - 22 in Quebec and 33 in Ontario - with mothers of young children living and employed in the Ottawa Valley. This was a non-probability purposive (and snowball) sample of employed mothers working in and around two economically stagnant, small urban centres near the Ontario/Quebec border, in the Ottawa Valley. The interviews were conducted in English in the women's homes, a community centre, or neighbouring locales, in Renfrew County, Ontario, and the Outaouais, in Pontiac County, Quebec.

All the women - who responded to ads placed in child-care centres, social services agencies, in local newspapers and radio, or heard through word of mouth, and volunteered to participate - were employed or near the end of a maternity leave and soon returning to paid work. These women, on both sides of the border, were employed in the service sector, as a lab technician, a freelance journalist, camp counsellor, in retail sales, in customer service call centres, in office management, child care, health care, and other social and public services. All but one woman in Quebec was either married or living common-law. Six of the women in Ontario were raising their children on their own (and/or with the help of extended family), while the rest had male partners. All but one interview (at the mother's request) were tape recorded, and about one hour in length. Albanese asked about women's employment history/background, and the impact that they believed that their paid work had on their household work, and their personal 
International Journal of Child, Youth and Family Studies (2015) 6(2): 252-274

relationships. She asked mothers about whether and how their roles and responsibilities at home, at work, and their overlap have changed with paid employment; and about who cares for their children, where, and at what cost. She also asked them who manages their child-care arrangements, and about how some of them manage child care in light of their own and/or their partners' non-standard jobs and changing work schedules and shifts.

The interviews in both Ontario and Quebec show that women are not actually free to choose whether to take employment outside their homes. The Ottawa Valley, like other parts of the country, has been spiralling into "economic crisis" for a number of years, with the decline of relatively well-paid, male-dominated jobs in the wood products and lumber industries. Increasingly, families rely on women's (at times low-waged) employment to make ends meet. In both jurisdictions, employed mothers were forced to make considerable sacrifices to balance work and child care. In fact, many mothers had to bend and stretch, skip lunch, lose wages, take on challenging shifts, reduce the number of hours they work, etc. to meet the challenges and demands associated with "balancing" paid work and child care. In both Ontario and Quebec, mothers (rarely fathers) were almost solely responsible for finding and managing the care of their children.

Low-fee child care in Quebec was certainly used and appreciated by mothers accessing care. Having the lower fee child care in Quebec made working part-time and still making ends meet possible for many mothers. That said, despite some changes in the gender division of labour outside the home, gender roles within the home changed only slightly. One Quebec mother who worked three part-time jobs, and was married to a farmer and lived on their farm, reported that she relied on her mother, mother-in-law, and two adolescent babysitters, on top of using $\$ 7.00$ per day child care, so that she could work on weekends and before and after her child care centre was open. She, like some other mothers interviewed on both sides of the provincial border, did not rely on her husband to help with child care or its management.

This woman's story also exemplified the experiences of many other Quebecoise mothers interviewed who either worked multiple part-time jobs or shift work in another way. That is, while child-care spaces in regulated, low-fee centres were available to them, the hours of operation (including family/home child care) were often inadequate to fit their work schedules and needs, forcing many to rely on networks of informal care, on top of the \$7.00 per day child care. Further, in both rural Ontario and Quebec, mothers travelled long distances to juggle paid work and child care.

In Ontario, both formal and informal child care was expensive. While many of the regulated child care spots in Renfrew County, Ontario, were subsidized (about 70\%, Albanese was told), many of the women interviewed were ineligible to receive subsidies, lost their subsidy for various reasons, or simply, and most commonly, could not find a subsidized spot in their own or in neighbouring communities. Many families in Ontario pay a great deal for both the (scarce) regulated spaces and (most common) unregulated spaces. 
International Journal of Child, Youth and Family Studies (2015) 6(2): 252-274

For example, one mother in Ontario admitted:

Right now we're paying almost \$1,000 a month, in child care, like that's a mortgage ... we don't qualify for subsidies, but we're still paying student loans. My husband and I make good money; and had we not had, you know, all those student loans, we'd be fine but, still it's very hard when you can't qualify for subsidy, but at the same time, you need quality care for your child. (2-008)

Many of the women interviewed in Renfrew County had their child(ren) in "lessthan-ideal" and often expensive unregulated care arrangements ["You get what you get. If the person is good with your kids, good; and if not, well...” (2-026)]. Even unregulated home care arrangements cost mothers more than \$30 and \$40 per day. Cost was a common answer for many when identifying the greatest challenge of meeting child care needs. One mother stated:

Well, I think number one for me is financial. 'Cause daily, I sort of sit back and think: Is this really worth it in the end, you know? It's almost comes down to a quality of life kind of thing, because you know we're driving all the time, and we're not really making that much money, and you know, maybe I should just be staying at home with my kids. But how can we, financially, as a family, do that? 'Cause we can't. That's the point. (2-021)

A mother of four who was originally from Quebec, then moved to Ontario, and finally returned to Quebec, in part because of the cost of child care, confided that when she lived in Renfrew County, Ontario:

And so I had a babysitter and I paid her, I forget what I paid her a day, but when it worked out, I made like \$11 a day; and that didn't take into account driving there...the price of gas last summer...so I just had to keep reminding myself that it was short term, you know. But basically, last summer I worked for free, so I don't know how people in the [region] who are making minimum wage can afford anything...I might as well have quit. I might as well not work, but I needed to work, and I really loved my job, like I still go back once a week to my old job to see everyone. Like I absolutely loved it, so, I had to do it, but I'm not going to do it to lose money, I'm not going to work 80 hours a week, or 80 hours in two weeks, to be in the hole. (1-005)

She added that once she moved to Quebec from Ontario, and got access to \$7.00 per day child care:

I was able to go from full-time work to part-time work...and yeah, we have the same amount of disposable income. And like I went from you know making a decent wage, to less, because you make less money here [in Quebec], and like I lost \$5 an hour [doing the similar work]. And um, so I was able to work less hours for less pay, and still have the same amount of income. (1-005) 
International Journal of Child, Youth and Family Studies (2015) 6(2): 252-274

In other words, her move to Quebec, which gave her access to $\$ 7.00$ per day child care, allowed her to choose to work fewer hours, spend more time with her children, and still manage to financially support her family. In Ontario, the cost of child care made this impossible, even when she worked longer hours at higher wages.

Another mother expressed great frustration at the cost of child care in Ontario. She explained that the hardest thing for her was "being tired at the end of the day, and then having that portion of my pay cheque have to go to pay for the child care” (2-031). She felt she worked hard, for long hours, with little to show financially after deducting the cost of child care.

Beyond the high financial costs associated with having children in child care, there were other obstacles as well. When asked about some of their biggest challenges, many turned to their struggle with actually making child care "work" - and managing their care arrangement on a daily basis. For example, when asked about their biggest challenges, mothers offered these comments:

One mother had to stitch together a patchwork of care arrangements to keep her job. She admitted that the most important factor for her daughter was consistency, something she lacked at the moment:

Just consistency, having quality care that's consistent. I'd love to be able to switch her to part time, but I don't like doing the switches. I think it's hard on her. I would like to just be able to keep her in one spot, and know that she's happy and know that she's safe and being cared for the way we want her to be cared for...being able to transition, maybe even in the same environment, so we're not going to three different place, you know...but I don't know when that's going to be. (2-008)

Those "fortunate" enough to have found an adequate child care arrangement worked extremely hard to make sure that it remained available and functioning. The situation got even more complicated when this precarious and delicate daily balancing act was disrupted by the illness of a child or child-care provider (not one mother mentioned her own illness as causing a problem).

Clearly, Canadian "society” and the Canadian state's family policies are still not adequately addressing the needs of employed mothers. Without wider family-friendly policies in place, when children got sick, mothers were sent scrambling. Some mothers admitted having to lie to employers, others described how they mobilized networks and resources to manage this all-too-common crisis.

I: Her dad's in Ottawa, so he's not here to help. I think the biggest challenge is when she's sick, or hurts herself. They're very, very strict at that daycare - like any kind of temperature, or fever, I have to be picked up right away. So I do miss a lot of work for her being sick. I would say that's a huge challenge, 'cause then I don't get paid. (2-007) 
International Journal of Child, Youth and Family Studies (2015) 6(2): 252-274

Ontario's social policies clearly do not reflect the needs of women and families. Mother scrambled, often in distress, to manage paid work and family responsibilities, including child care. While allowing them to stay employed, some mothers' child care arrangements were a source of almost constant stress. Balancing paid work and family responsibilities wore some mothers thin and forced others into desperate situations. For example, after the interview, one mother mentioned in passing that she sometimes sends her daughters to bed fully dressed, so she is ready to quickly leave the house in the morning. Another mentioned that some of their meals are eaten in the car on the way to the "sitter's" (breakfast) or on the way back, at the end of the day (some light suppers). Many spoke of the challenges coordinating it all:

Getting out the door. Making sure that everybody's prepared. Making sure I'm prepared for work. Making sure they're all prepared for school. You know making sure that I've had breakfast before I make it to work.... (2-030)

Just trying to squeeze it all in one day. I guess just trying to be on time. Trying to be organized. Trying to take care of me and my two boys. It's like dressing myself three times, feeding myself three times [laughs]. (2-018)

Things that have changed. I definitely have a lot more stress as far as home preparation that has to be done in order to get out in the morning...The difficulty of child care, like it has changed our life quite a bit. (2-020)

The problem is clear: Children and child care are treated as private matters and individual lifestyle "choices". Children are not seen as socially valuable and mothers continue to disproportionately bear the weight of social reproduction. Mothers sacrifice a great deal, including sleep, having more children, working the number of hours they wanted or needed to work, etc. Some in tears, others in frustration admitted:

We don't want to have any more [children] because of money, because of space, because of the amount of time it's taken away. Now he's [her son] going to be growing up with no brothers and sisters and it's hard on him because he never has anybody to play with at home or on the weekends. You know, it's always us, it puts that extra demand on us again to have to be his little buddy, or his friend, you know. (2-020)

It was just hard for me when I was in the classes. I would have 6 hours maximum of sleep. And I tried to complete all of my assignments during the week so that I could have the weekends off [to spend with her children]. (2-010)

I had to give up a really great job because I didn't have child care...I couldn't afford to pay rent, pay a babysitter, and continue working that job...I was actually offered the supervisor [position]...and I'd be in charge of it all, and it entailed shift work; and I could not do it. I had to give it up...it was really difficult. (2-029) 
International Journal of Child, Youth and Family Studies (2015) 6(2): 252-274

With too few social supports in place, while working extremely hard to make it all come together, far too many of the women sounded defeated because of the situation they found themselves in, and no doubt, this affected their children. For example, three mothers shared the following:

I'm no longer at work in the network. I recognized my limits, and with a bit of reservation, I have withdrawn my volunteer activity... I just have to know my limits. I'm tired. I'm exhausted. And, I keep telling myself this is temporary, and I'm not the first one that has gone through this...but I'm living it now and I'm having difficulty. (2-009)

I'm kind of worried about it [finding paid work and affordable child care] because I don't know if I'll be working. I'm hoping I'll be working. I don't really want to go back on assistance, go through all this hard work for a year [taking courses at a local college] and just end up falling back to where I was. It's hard. I don't want to be working at Walmart or McDonald's. That won't be enough to pay for day care, and that'll be shift work. I'm not really looking forward to it. (2-018)

So even though his wage isn't that much more than mine .... He wouldn't jeopardize his job for anything, it would be mine that would take the back seat. I just don't see that being the right choice either. (2-019)

Balancing paid work and child care is a big challenge for many women in this country, and especially for women living outside of Quebec (despite shortcomings in Quebec policy). The women interviewed, especially those in Ontario, sacrificed their relationships, their careers, and their well-being. Some mothers shed tears in frustration, some shook their fists in anger; some shrugged their shoulders in defeat. The child-care predicament these women find themselves in has resulted in a great deal of stress and worry, which inevitably affects their children's well-being. Most mothers interviewed recognized this but felt that the sacrifices that they made were short-term, until their children entered the formal school system. They also knew that if they remained outside the labour force for the years that their children needed child care, their job prospects diminished and their diplomas, degrees, and credentials could be considered out of date or obsolete. They acknowledged that not working for pay was not an option, as it would result in increased, and possibly long-term, financial strain if not ruin on their families. This, they knew, would harm their children even more.

\section{Conclusion}

Families increasingly depend on women's wages to make ends meet. As a result, despite some changes in gender roles and expectations, mothers continue to be seen as the ones primarily responsible for making child-care arrangements and juggling to "balance" paid and unpaid work. Women with young children need child care but the limited number of regulated spaces that do exist remain expensive and out of reach for most mothers. Mothers, especially outside of Quebec, face many challenges, daily, when 
trying to manage their families' child-care needs. Without a doubt, as noted above, this stress and frustration negatively affected the lives of their children, but the alternative was not an alternative at all. Not working for pay would put many families in economically precarious positions - doubly disadvantaging children. The solution is obvious. Mothers need affordable, accessible, high-quality child care that will allow them to better balance paid work and family responsibilities. The well-being of Canadian children depends on it.

Despite this growing reality, coverage of this issue in Canadian daily newspapers is scant, except during federal election campaigns when political parties were using the child care debate as a wedge issue. We found that child care seldom occupied the spotlight, and often virtually disappeared off the pages, despite the daily challenges faced by many Canadian families. The voices and stories of Canadian families and mothers were rarely featured in news stories even though many need and favour a publicly funded child-care system. 
International Journal of Child, Youth and Family Studies (2015) 6(2): 252-274

\section{References}

Abner, K., Gordon, R., Kaestner, R., \& Korenman, S. (2013). Does child-care quality mediate associations between type of care and development? Journal of Marriage \& Family, 75(5), 1203-1217. http://dx.doi.org/10.1111/jomf.12055

Akyeampong, E. B. (2007). Canada's unemployment mosaic, 2000 to 2006. Catalogue no. 75-001-XIE. Ottawa: Statistics Canada.

Albanese, P. (2006). Small town, big benefits: The ripple effect of \$7/day child care. Canadian Review of Sociology and Anthropology, 43(2), 125-140. http://dx.doi.org/10.1111/j.1755-618x.2006.tb02216.x

Albanese, P. (2011a). The more things change... The more we need child care, on the fortieth anniversary of the Report on the Royal Commission on the Status of Women. In L. Tepperman \& A. Kalyta (Eds.), Reading sociology (pp. 95-98). Toronto: Oxford University Press.

Albanese, P. (2011b). Addressing the interlocking complexity of paid work and care: Lessons from changing family policy in Quebec: A life in balance? In C. Krull \& J. Sempruch (Eds.), Reopening the family-work debate (pp. 130-143). Vancouver: UBC Press.

Albanese, P., Rauhala, A., Johnstone, J., Ferns, C., \& Lam, J. (2010). Hiding the elephant: Child care coverage in four daily newspapers. Journal of Comparative Family Studies, 41(5), 817-836.

Albanese, P., Rauhala, A. \& Hache, L. (in press). Childcare - Clearly not a 'woman's issue': Assessing the coverage of childcare in Canadian newspapers during the 2004 and 2006 federal elections. In J. Newman (Ed.), Title of volume to be announced. Toronto: Oxford University Press.

Baker, M. (2006). Restructuring family policies: Convergences and divergences. Toronto: University of Toronto Press.

Ballantyne, M. (2008). Harper and child care. In T. Healy (Ed.), The Harper record (pp. 339-344). Ottawa: Canadian Centre for Policy Alternatives.

Bégin, L., Ferland, L., Girard, G., \& Gougeon, C. (2002). School daycare services (Gouvernement du Québec, Catalogue No. 2002-02-00121). Québec: Gouvernement du Québec.

Bernard, A., \& Usalcas, J. (2014). The labour market in Canada and the United States since the last recession. Economic Insights. 11-626X-No.036. Ottawa: Statistics Canada. 
International Journal of Child, Youth and Family Studies (2015) 6(2): 252-274

Canadian Newspaper Association. (2008). The scoop on Canadian newspapers. Toronto: Author. Retrieved from http://www.cnaacj.ca/en/system/files/The\%20Scoop\%20on\%20Canadian\%20Daily\%20Newspap ers\%20WEB.pdf

Chawla, R., \& Uppal, S. (2012). Household debt in Canada. Perspectives on Labour and Income, 24(2), 1-15. Ottawa: Statistics Canada.

Child Care Canada. (2003). Multilateral framework on early learning and child care. Toronto: Author.

Conservative Party of Canada. (2006). Stand up for Canada: Conservative Party of Canada (Federal election platform, 2006). Retrieved from http://www.cbc.ca/canadavotes2006/leadersparties/pdf/conservative_platform200 60113.pdf.

Cottle, S. (2003). News, public relations and power. London: Sage. http://dx.doi.org/10.4135/9781446221594

Cross, P. (2007). GDP and employment growth. Perspectives on Labour and Income, 8(3), 14-23.

Davis, A. (2003). Whither mass media and power? Evidence for a critical elite theory alternative. Media, Culture \& Society, 25(5), 669-690. http://dx.doi.org/10.1177/01634437030255006

De Swert, K., \& Hooghe, M. (2010). When do women get a voice? Explaining the presence of female news sources in Belgian news broadcasts (2003-5). European Journal of Communication, 25(1), 69-84. http://dx.doi.org/10.1177/0267323109354229

Dorfman, L., \& Woodruff, K. (1999). Child care coverage in the U.S. newspapers. Issue 7. Berkeley, CA: Berkeley Media Studies Group. Retrieved from http://www.bmsg.org/pdfs/Issue7.pdf

Esping-Andersen, G. (1990). The three worlds of welfare capitalism. Princeton, NJ: Princeton University Press.

Ferns, C., \& Friendly, M. (2014). The state of early childhood education and care in Canada 2012. Moving Childcare Forward Project. A joint initiative of the Childcare Resource and Research Unit, Centre for Work, Families and WellBeing at the University of Guelph, and the Department of Sociology at the University of Manitoba. Toronto: Movingchildcareforward.ca.

Ferrao, V. (2010). Paid work. Women in Canada: A gender-based statistical report. (Catalogue no. 89-503-X). Ottawa: Statistics Canada. Retrieved from http://www.statcan.gc.ca/pub/89-503-x/2010001/article/11387-eng.pdf. 
International Journal of Child, Youth and Family Studies (2015) 6(2): 252-274

Friendly M., Beach, J., \& Turiano, M. (2002). Early childhood education and care in Canada 2001. Toronto: Childcare Resource and Research Unit, University of Toronto.

Friendly, M., Beach, J., Ferns, C., \& Turiano, M. (2007). Early childhood education and care in Canada 2006. Toronto: Childcare Resource and Research Unit, University of Toronto.

Friendly, M., \& Prentice, S. (2009). About Canada: Childcare. Halifax, NS: Fernwood Publishing.

Galarneau, D. (2010). Temporary employment in the downturn. Perspectives on Labour and Income, 11(11), 1-15. Ottawa: Statistics Canada.

Gidengil, E., \& Everitt, J. (2003). Conventional coverage/unconventional politicians: Gender and media coverage of Canadian leaders’ debates, 1993, 1997, 2000. Canadian Journal of Political Science, 36(3), 559-577. http://dx.doi.org/10.1017/s0008423903778767

Gidengil, E., Everitt, J., Blais, A., Fournier, P., \& Nevitte, N. (2006). Gender and vote choice in the 2006 Canadian Election. Paper prepared for the Annual Meeting of the American Political Science Association, Philadelphia, PA.

Gidengil, E., Hennigar, M., Blais, A., \& Nevitte, N. (2005). Explaining the gender gap in support for the new right: The case of Canada. Comparative Political Studies, 38(10), 1171-1195. http://dx.doi.org/10.1177/0010414005279320

Globe and Mail. (2010). When you need real results from your media partner look no further than Globe Media Group. Toronto: Author. Retrieved from http://www.globelink.ca/newspaper/about/.

Government of Canada. (1997). National children's agenda (\& amendments). Retrieved from http://www.socialunion.ca/nca/June21-2000/english/index_e.html.

Government of Canada. (2001). Federal/provincial/territorial early childhood development agreement in 2000. Ottawa: Author. Retrieved from http://publications.gc.ca/site/eng/104882/publication.html.

Government of Canada. (2004). A Canada fit for children: Canada's plan of action in response to the May 2002 UN Special Session on Children. Ottawa: Author. Retrieved from http://www.hrsdc.gc.ca/eng/cs/sp/sdc/socpol/publications/2002002483/canadafite.pdf

Government of Canada. (2006). Universal child care plan. Ottawa: Author. Retrieved from http://www.universalchildcare.ca/en/faqs_benefit.shtml 
International Journal of Child, Youth and Family Studies (2015) 6(2): 252-274

Government of Canada \& Government of Quebec. (2005). Canada-Quebec agreement on early learning and child care: Funding agreement. Toronto: Childcare Resource and Research Unit. Retrieved June 5, 2007, from http://action.web.ca/home/crru/rsrcs_crru_full.shtml?x=82553.

Government of Quebec. (2003). Development and funding scenarios to ensure the permanence, accessibility and quality of childcare services: Consultations 2003. Québec: Ministère de L’Emploi, de la Solidarité sociale et de la Famille.

Government of Quebec. (2006). Family and childcare services - Childcare services. Retrieved June 4, 2007, from http://www.mfa.gouv.qc.ca/thematiques/famille/services-garde/type/index_en.asp,

Greenberg, J. (2000). Opinion discourse and Canadian newspapers: The case of the Chinese Boat People. Canadian Journal of Communication, 25(4), 517-537.

Hübenthal, M., \& Ifland, A. (2011). Risks for children? Recent developments in early childcare policy in Germany. Childhood, 8(1), 114-127. http://dx.doi.org/10.1177/0907568210372430

Hughes, K., \& Lowe, G. (2000). Surveying the "Post-Industrial” landscape: Information technologies and labour market polarization in Canada. Canadian Review of Sociology and Anthropology, 37(1), 29-53. http://dx.doi.org/10.1111/j.1755-618x.2000.tb00585.x

Immervoll, H., \& Barber, D. (2005). Can parents afford to work? Childcare costs, taxbenefit policies and work incentives. OECD Social, Employment and Migration Working Papers, No. 31. Paris: OECD Directorate for Employment, Labour and Social Affairs. Retrieved from www.oecd.org/dataoecd/58/23/35862266.pdf

Jenson, J. (2001). Family policy, child care and social solidarity: The case of Quebec. In S. Prentice (Ed.), Changing child care: Five decades of child care advocacy \& policy in Canada (pp. 39-62). Halifax, NS: Fernwood Publishing.

Krull, C. (2007). Families and the state: Family policy in Canada. In D. Cheal (Ed.), Canadian families today: New perspectives (pp. 254-272). Don Mills, ON: Oxford University Press.

Kunkel, D., Smith, S., Suding, P., \& Biely, E. (2002). Coverage in context: How thoroughly the news media report five key children's issues. College Park, MD: University of Maryland, Casey Journalism Center on Children and Families.

LaRochelle-Côté, S., \& Uppal, S. (2011). The financial well-being of the self-employed. Perspectives on Labour and Income. 23(4), 3-15. Ottawa: Statistics Canada. 
International Journal of Child, Youth and Family Studies (2015) 6(2): 252-274

McManus, M., \& Dorfman, L. (2002). Silent revolution: How U.S. newspapers portray child care. Issue 11. Berkeley, CA: Berkeley Media Studies Group. Retrieved from http://www.bmsg.org/pdfs/Issue11.pdf

Morissette, R., \& Ostrovsky, Y. (2005). The instability of family earnings and family income in Canada, 1986 to 1991 and 1996 to 2001. Canadian Public Policy, 31(3), 273-302. http://dx.doi.org/10.2307/3552442

National Children's Alliance. (1998). National children's agenda. Ottawa: Author. Retrieved from http://www.nationalchildrensalliance.com/nca/pubs/investing.html

Organisation for Economic Cooperation and Development (OECD). (2004). OECD thematic review of early childhood education and care: Canada country note. Paris: Author.

Organisation for Economic Cooperation and Development (OECD). (2006). Starting strong 2. Paris: Author.

Rauhala, A., Albanese, P., Ferns, C., Haniff, A., Law, D., \& Macdonald, L. (2012). Who says what: Pre- and post-election coverage and sourcing of child care in four Canadian dailies. Journal of Child and Family Studies, 21(1), 95-105. http://dx.doi.org/10.1007/s10826-011-9481-0

Rinehart, D. (2007). The daycare campaign revisited: From baby steps to beer and popcorn. Policy Options, 29(7), 47-52.

Rinehart, D. (2008). Baby talk: How gender issues affected media coverage of the childcare debate in the last federal election. Canadian Journal of Media Studies, 4(1), $1-40$.

Roy, F. (2006). From she to she: Changing patterns of women in the Canadian labour force. Canadian Economic Observer, 19(6), 3.1-3.10. Ottawa: Statistics Canada.

Roy, L., \& Bernier, J. (2007). Family policy, social trends and fertility in Quebec: Experimenting with the Nordic model? Quebec: Ministère de la Famille, des Aînés et de la Condition Féminine.

Royal Commission on the Status of Women. (1970). Report of the Royal Commission on the Status of Women. Ottawa: Information Canada.

Scherer, R. (2001). Federal child care policy development: From World War II to 2000. In S. Prentice (Ed.), Changing child care (pp. 187-198). Halifax, NS: Fernwood.

Statistics Canada. (2012). The Canadian population in 2011: Age and sex. Catalogue Number 98-311-X2011001. Ottawa: Minister of Industry. 
International Journal of Child, Youth and Family Studies (2015) 6(2): 252-274

Statistics Canada. (2013). 2011 National household survey: Portrait of Canada's labour force. The Daily, June 26, 2013. Ottawa: Author.

Statistics Canada. (2014). Labour force survey, June 2014. The Daily, July 11, 2014. Ottawa: Author.

Teghtsoonian, K. (1993). Neo-conservative ideology and opposition to federal regulation of child care services in the United States and Canada. Canadian Journal of Political Science, 26(1), 97-121. http://dx.doi.org/10.1017/s000842390000247x

Teghtsoonian, K. (1995). “Work and/or motherhood”: Ideological construction of women's options in Canadian child care policy debates. Canadian Journal of Women \& the Law, 8(2), 411-439.

Theriault, L. (2006). The National Post and the nanny state: Framing the child care debate in Canada. Canadian Review of Social Policy, 56, 140-148.

Tougas, J. (2001a). What we can learn from the Quebec experience. In G. Cleveland \& M. Krashinsky (Eds.), Our children's future: Child care policy in Canada (pp. 92-105). Toronto: University of Toronto Press.

Tougas, J. (2001b). Child care in Quebec: Where there's a will, there's a way. Ottawa: Child Care Advocacy Association of Canada. Retrieved from http://www.ccaac.ca/pdf/resources/QUE_CHILDCARE.pdf

Tougas, J. (2002a). Reforming Quebec's early childhood care and education: The first five years (Occasional Paper 17). Toronto: Childcare Resource \& Research Unit, Centre for Urban \& Community Studies.

Tougas, J. (2002b). Quebec's family policy and strategy on early childhood development and childcare. Education Canada, 39(4), 20-22.

Warner, M., \& Prentice, S. (2013). Regional economic development and child care: Toward social rights. Journal of Urban Affairs, 35(2), 195-217. http://dx.doi.org/10.1111/j.1467-9906.2012.00622.x

White, M. (2003). Retraining programs for displaced workers in the post-industrial era: An exploration of government policies and programs in Canada and England. Compare: A Journal of Comparative and International Education, 33(4), 497506. http://dx.doi.org/10.1080/0305792032000127784 